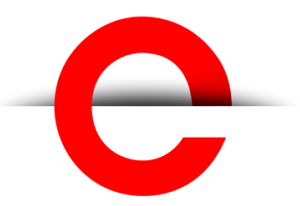

U T S

e PRES S

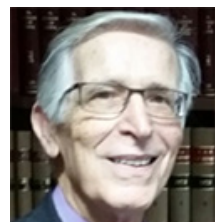

International Journal

of Rural Law and

Policy

No. 2, 2019
ARTICLE (NON-REFEREED)

\section{Equal or unequal opportunities within the criminal justice system from a rural and regional perspective}

\author{
John Nicholson SC \\ Australia. john.nicholson222abigpond.com \\ Research Assistant: Amanda Warren (UNE, Australia) \\ DOI: https://doi.org/10.5130/ijrlp.2.2019.6548 \\ Article History: Received 17/12/2018; Revised 07/07/2019; Accepted 10/07/2019; \\ Published 06/08/2019
}

\section{ABSTRACT}

Approximately a third of NSW criminal charges are dealt with in rural and regional courts. About a third of prisoners in NSW goals come from rural and regional NSW. However, resources - legal and therapeutic - available for rural and regional defendants do not match those available for offenders located in metropolitan areas. Twenty-one significant disparities are identified. Three sources of these disparities are also identified - court proceedings, geographical remoteness, and government failures. The majority of identified disparities, it is argued, is attributable to government failure. Recent changes to sentencing law and practices in the administration of sentences are looked at from a rural perspective and potential new and continuing disparities are identified. The limitations arising from the disparities to the exercise of judicial discretion with a rural setting are explained, particularly with reference to sentencing.

\section{Keywords}

rural crime; criminal justice system; disparities between regional and metropolitan courts; geographic remoteness; rural and regional court proceedings; limitations on judicial discretion; alternatives to imprisonment
1
DECLARATION OF CONFLICTING INTEREST The author(s) declared no potential conflicts of interest with respect to the research, authorship, and/or publication of this article. FUNDING The author(s) received no financial support for the research, authorship, and/or publication of this article. 
U T S

e PRES S

\section{Identifying the field}

It has long been the tradition that the monarch of the day is responsible for keeping peace throughout his or her realm. In these days it is the Queen's peace that is breached whenever a crime or criminal disturbance occurs. Prosecutions of indictable crimes are undertaken by the State in the name of the monarch. In 2017 the NSW criminal courts finalised 344,176 breaches of the Queens peace by way of charges against 141,024 defendants. ${ }^{1}$ Around 90 per cent of defendants were found guilty of at least one charge. ${ }^{2}$ Offences dealt with by the courts ranged from unauthorised driving offences $(21,000+\text { persons })^{3}$ through to homicides (145 accused found guilty). ${ }^{4}$ The outcomes of these 344,176 charges will have ranged from acquittals (10\%), through to discharges without conviction, fines, bonds to be of good behaviour - with or without supervision, intensive corrections orders, sentences of imprisonment including suspended sentences, home detention or fulltime incarceration.

Ninety percent of criminal matters are finalised in the Local Court. ${ }^{5}$ In addition to driving offences, the Local Court handles general assaults, domestic violence matters, other acts of violence that do not progress to the higher courts, and many break-and-enter offences. The other 10 percent of criminal offences, dealt with by the higher courts, constitute matters of greater seriousness, including major drug offences, major fraudulent dealing offences, sexual assaults, violent offences, including homicides, aggravated versions of break-and-enters, aggravated robberies and terrorism type charges.

If the 2009 figures offer any general guide for NSW, the Local Courts are responsible for 80 per cent of sentenced prisoners, while the higher courts account for 20 per cent. ${ }^{6}$ In the 12 months ending March 2018, the courts sent 18,530 offenders into custody, while the prisons discharged 18,021 - a growth rate of 509 inmates. ${ }^{7}$ If one includes The Central Coast, Newcastle and Lake Macquarie, and The Illawarra as part of regional NSW, then it would appear about a third of all NSW prisoners come from rural, regional and remote NSW. The major contributors are Newcastle and Lake Macquarie (5\%), Central Coast (4.5\%), Mid North Coast and Illawarra (4.2\%), New England and North West (3.6\%), Hunter Valley (3.4\%) and Far West and Orana (3.1\%). ${ }^{8}$ Interestingly, and by way of contrast, the statistical picture for Aboriginal prisoners differs: two-thirds of the Aboriginal prison population appear to come from the bush. The major contributors are: Far West and Orana (9.9\%), New England

\footnotetext{
1 Bureau of Crime Statistics and Research (Boscar), 'Criminal Court Statistics 2017' (Media Release, 29 May 2018) <www.boscar.nsw.gov.au/Pages/boscar_media_releases/2018mr-NSW-Criminal-CourtsStatistics-2017.aspx>.

2 Ibid.

3 Suzanne Poynton and Felix Leung, 'Early Indicators of the Impacts of the NSW Driver Licence Disqualification Reforms' (Issue Paper No 135,NSW Bureau of Crime and Research Statistics, August 2018).

4 Bureau of Crime Statistics and Research (Boscar) 'Criminal Court Statistics: NSW Criminal Courts Snapshot: Court Workload by Offence Type, 2017' <www.boscar.nsw.gov.au/Pages/boscar_court_stats/ boscar_courts_stats.aspx>.

5 Local Court of New South Wales, Local Court of New South Wales: Annual Review 2017 (Report, 2018) 4.

6 Jessie Woodburn, Katrina Grech and Don Holmes, "Why Does NSW have Higher Imprisonment Rates than Victoria' (2019) 145 Crime and Justice Bulletin; see also <www.bocar.nsw.gov.au/Documents/CJB/ cjb145.pdf>.

7 NSW Bureau of Statistics and Research, NSW Custody statistics *Quarterly update, March 2018).

8 S Corben, NSW Inmate Census 2016 - Summary of Characteristics (Statistical Publication No 45, ISSN 08144 1215, October 2017, Corrective Services NSW).
} 
U T S

e P R E S S

and North West (9.3\%), Mid North Coast (8.5\%); Newcastle and Lake Macquarie (5.4\%) and Central West (5\%). ${ }^{9}$

Accepting the present prison population (remand and sentenced) is about 13,800, more than 11,000 of them are likely to be there because of an alcohol and/or drug-related crime. Of the 120,000 other offenders sentenced to something less than imprisonment, at least 100,000 were, on my calculation, involved in an alcohol and/or drug-related crime. The role of the alcohol and/or drug phenomenon becomes even more significant if one includes undetected or unpursued drug and/or alcohol related criminal offending. Putting to one side any successes compulsory drug treatment may have at Parklea and Windsor correction facilities; a consequence of untreated addiction is that it easily survives imprisonment. The overwhelming bulk of recidivist offenders will be abusing drugs, whether prescription, illicit or alcohol, while in custody and upon release. A higher proportion of people in outer regional areas and remote and very remote areas had used an illicit drug compared to people in major cities or inner regional areas. People living in remote and very remote areas were found to be twice as likely as people in major cities to have recently used meth/amphetamines, cannabis and pharmaceuticals (not for medical purposes). ${ }^{10}$

In much of the work done by agencies within the criminal justice system, alcohol and drugs - both legal and illicit - are an important focus because of their causal effects. Police detecting and investigating drug-related crime; lawyers, court staff and judicial officers in dealing with offenders involved in drug-related crime; Corrective Services, including Community Corrections staff in administering sentences - both custodial and non-custodial; and a growing industry of post-release service to inmates paroled to half-way houses are all dealing, one way or another, with the consequences of drug addiction.

\section{A 2015 health survey involving about ten percent of the adult prison pop- ulation revealed 67 per cent of the males and 63 per cent of the females consumed alcohol at levels considered hazardous. A whopping 85 per cent of participants reported misusing drugs other than alcohol. ${ }^{11}$}

During my time on the bench, which ended in 2012, I noticed greater use of more potent drugs; greater sophistication in distribution of drugs by manufacturers and importers; addicts more physically and mentally damaged by their addiction than was the case in previous years; a greater level of disinhibited violence as a side effect of methamphetamine (ICE) consumption; and older age groups involved in drug-related offending. The prosecution of small-time drug dealers charged with multiple supplies increased with the introduction of laws and increased penalties targeted at small-time dealers. Small-time dealers most frequently dealt to support their own big-time drug use. Recidivism and Indigenous incarceration rates climbed.

The courts are a crucial part of the criminal justice system - a phrase that embraces a concept far wider than courts. The criminal justice system covers a field including the detection and investigation of criminal conduct; the charging of alleged offenders, the preparation and presentation of litigation associated with trials and sentencing arising out of criminal

9 Ibid.

10 National Rural Health Alliance, Illicit Drug Use in Rural Australia (Factsheet 33, June 2015) 2 <http:// ruralhealth.org.au/sites/default/files/publications/nrha-factsheet-illicit-drugs-0615.pdf>.

11 Justice Health and Forensic Mental Health Network, Network Patient Health Survey 2015 14; see also Health - Justice Health \& Forensic Mental Health Network, 2015 Network Patient Health Survey Report $<w w w . j u s t i c e h e a l t h . n s w . g o v . a u / p u b l i c a t i o n s / 2015$ NHPS_FINALREPORT.pdf $>$. 
U T S

e PRES S

matters; the work of the NSW criminal courts set out above, the work of those responsible for overseeing the execution of any sentences - Community Corrections officers supervising Intensive Correction Orders, Community Correction Orders and Conditional Release Orders through to Corrections officers and others (doctors, psychologists, welfare workers and program presenters and the like) working within the prison system. Indeed, in the post-prison release setting, there is a small number of NGOs, such as The Rainbow Lodge Program, ${ }^{12}$ working with a small number of high-risk inmates released to parole by assisting them to reenter the community without relapsing into criminal behaviour.

The Criminal Justice system consumes a sizeable portion of the NSW State budget. The 2017-2018 budget includes allocations to police of $\$ 3.5$ billion (expenses) plus $\$ 244$ million (capital expenses); Legal Aid \$300 million; courts \$623 million; Offender Management and Rehabilitation $\$ 1.8$ billion (expenses) plus $\$ 1.5$ billion (capital expenses). ${ }^{13}$ Of course, not all of that $\$ 6.7$ billion is spent on keeping the Queens peace - but a substantial percentage of the big-ticket items - police, offender management and rehabilitation and court costs are so spent.

It is unrealistic to measure the path to incarceration only in terms of dollars spent by government. The true cost of incarceration is not confined solely to government. Costs are also experienced by incarcerated persons, their families and work places. I don't know if anyone has worked out the financial loss to our community of 13,800 incomes (including social benefits) withdrawn from various communities - but I suggest it runs to a figure above $\$ 100$ million annually. Unlike retired judges, doctors and other professionals, whatever the figure, given the background of an overwhelming majority of inmates, it is safe to speculate that most of that lost income would have been spent on household and consumer items; that is, in a way that most benefits local businesses.

More importantly, there are the human costs: families required to live on a diminished income, food and heating insecurity, emotional loss of an important family or community member (father mother, carer, partner). Incarceration facilitates family break-ups and festers custody battles over children. Smaller communities experiencing multiple incarcerations may see increases in crime. ${ }^{14}$ Deterioration of physical and mental health are common consequences of prison life; likewise, institutionalisation, homelessness, loss of employment and entrenched addiction. The barbarity of imprisonment ensures the overwhelming majority of inmates leave prison as more damaged persons than when they entered the prison gates. These costs long survive a prison sentence and continue in health, mental health, housing and recidivism costs.

So, here's the thing! At least $\$ 4$ billion of the 2017-18 State budget, together with substantial community financial and personal costs, are about keeping the Queen's peace in circumstances where, in at least 80 per cent of breaches of the Queen's peace, drugs and alcohol played a part. Surely such a situation poses the Elephant-in-the-room question for a rural and regional populous. Is there a better, fairer and more humane way for rural and remote delivery of services to achieve the same or a better Queen's peace outcome?

12 Named after Judge Rainbow QC, former Judge of the Workers Compensation Commission, and former president of the Australian Prisoners' Aid Society.

13 NSW Budget Estimates, 2017-18, 7 Justice Cluster <www.budget.nsw.gov.au/sites/default/files/ budget-2017-06/7\%20Justice\%Cluster.pdf>.

14 J Nicholson, 'Reconsidering Traditional Custodial Sentencing Policies and Practices' (2018) 147 Precedent. 


\section{Opportunities and resources lost}

It is within this wide context the question of whether rural and regional centres are receiving opportunities to play their part in the criminal justice system equal to those enjoyed in metropolitan Sydney. I took this question to some colleagues and, particularly, to the members of the Bondie ${ }^{15} \mathrm{Club}-\mathrm{a}$ Facebook club of solicitors and barristers who practice criminal law throughout the State. Their list of unequal opportunities included most of the items below:

- An absence of specialist Children's Courts and Children's Court Magistrates (of relevance to those offenders and alleged offenders younger than 18 years from rural, regional and remote areas - mostly Indigenous youth).

- An absence of specialist Coroner's Courts and Coroners (of relevance in those coronial inquiries where a potential finding of criminal conduct is an issue).

- An absence of specialist Drug Courts (of relevance to $85 \%$ of prison inmates).

- An absence of Circle Sentencing Courts and the challenges in bringing together Indigenous community members and appropriate legal staff to run such Courts (of relevance to $67 \%$ of Indigenous prisoners).

- No rural or regional gaols offering a compulsory drug program.

- Severely limited availability in regional areas of affordable drug detox and rehabilitation drug beds and other facilities (of relevance to addicts whether involved in criminal conduct or not).

- An absence of post-custody release centres focused on rehabilitation and re-entry into communities for high-risk and homeless inmates ( $70 \%$ to $100 \%$ recidivism rates in some categories of rural, regional and remote offenders).

- Inadequate facilities in the smaller Local Courts and some Police stations for private conferences involving custody clients and their legal representatives. Existing problems are aggravated where Indigenous clients have hearing problems.

- No capacity to make community service placements in some areas.

- Low access to Court referred programs such as MERIT.

- Limited reception for ankle attached monitoring devices.

- No or limited access to a Justice Health nurse on-site at regional and rural courts (Of importance to offenders and alleged offenders, particularly those with mental health problems).

- Greater impact upon driving offenders who receive driving disqualification - absence of public transport, greater distances between destinations, greater police oversight because of less traffic and greater incidence of police personal knowledge of offender, difficulties getting their interlock devices serviced or calibrated.

- Clients with mental health issues, causing original offence, need extended hospitalisation and this results in a loss of accommodation. When these people leave hospital, they are often bail refused because of the absence of a permanent address. This means they cannot be referred to a local mental health team. Without a mental health team in place, they can't secure accommodation.

- Access to District and Supreme Courts compromised, meaning trials that are not reached in one sitting must wait for substantial periods until the next sittings of the Court are scheduled. For accused persons in custody, this can result in both extension of

15 Name inspired by Greg Bond, a long-time solicitor with the Aboriginal Legal Service until his demise in 2014. 
U T S

e PRES S time in custody and being relocated to a different regional centre, which in turn impacts adversely upon witnesses and support persons.

- Closure of some regional Local Courts and District Courts resulting in people needing to travel hundreds of kilometres to access a court. This may result in persons unhappy with a Local Court decision foregoing or abandoning a conviction or severity appeal to the District Court because the costs of travel (money and time) may be greater than the penalty and/or conviction imposed, especially if the penalty was non-custodial. In the event of a subsequent conviction, the unchallenged conviction/penalty becomes part of the offender's past criminal record.

- Add-on costs for retaining legal representation sourced from Sydney, Brisbane or Melbourne. Usually, in addition to usual appearance and preparation time, there will be travel, accommodation and, perhaps, other costs to be met that do not apply in metropolitan centres.

- Local Court Magistrates in smaller centres may have difficulty in maintaining their anonymity. Local press coverage of court matters and results in regional Local Courts is greater than Magistrates in Metropolitan Court centres would experience. This can sometimes lead to Magistrates receiving unwelcome feedback, thereby increasing their stress levels.

- Advocates appearing constantly before the same Magistrate and/or against the same police prosecutor and/or legal representative appearing for another party may compromise submissions or arguments or, even, cross-examination that should be made for one client on the basis that the greater good to other clients requires the advocate to 'keep on-side' the Magistrate, prosecutor and/or other legal representative.

- On rare occasions, when a judicial officer (or even more rarely, a legal representative) has to recuse himself/herself because of a conflict of interest or a reasonable apprehension of bias, the scheduled hearing normally needs to be adjourned until a replacement judicial officer (or legal representative) is available. That could be at another town's courthouse (involving travel) or at another sitting presided over by a different judicial officer in the same courthouse (involving delay and quite possibly travelling).

- Offenders sentenced to custody may be located in custodial settings far from the postcode where their home is located, their community, family and/or support person live, or where the sentence was imposed.

- A scarcity of juvenile detention centres in regional areas means some juvenile accused persons who have been refused bail and are housed in metropolitan detention centres have to be flown in to regional and remote courts for the hearing of their charges.

The absence of specialist courts and the specialist judicial officers presiding in them can best be likened to having a GP deal with a medical problem where others in the city would have the services of a specialist in the relevant medical disciplinary field.

\section{SOURCING THE ORIGINS OF THE INEQUALITIES}

The inequality of opportunities including those identified above appear to spring from three sources: some failure amounting to unfairness or inequity arising out of court proceedings; the existence of unfavourable circumstances arising out of geographical remoteness; and a failure of government to be fair or ensure equality of opportunity within the criminal justice system to rural and regional sectors. 
As to failures amounting to unfairness or inequity arising out of court proceedings, there is no real loss of opportunity when seeking to remedy in such a situation. Court practices and procedures are designed to minimise such unfairness or inequity occurring at first instance and in the event there is concern at the conclusion of a trial or sentence proceedings then putting to one side the question of remoteness identified above, the question of appeal opportunities is otherwise consistent throughout the State.

Loss of opportunities for equality of treatment arising out of geographical remoteness are likely to be beyond the scope of a court or government to remedy without advances in communication technology. Limited access to legal representatives and more expense for their services, and massive travel distances (in the absence of more regional courts) is one of the tensions of rural life to be balanced against its benefits. However, many people live in rural and remote areas by necessity or because of family and kinship ties rather than by choice. Children will usually have little choice about where their family lives. No doubt the existence of such tensions should be a well-recognised fact to which a court should give sympathetic consideration when circumstances of remoteness are relevant.

The first 12 of the 22 bullet-list of loss of equal opportunities identified above, are arguably a consequence of government failure to be fair or ensure equality of opportunity within the criminal justice system in rural and regional sectors. The failure is long-standing. Governments of both persuasions are equally responsible for the impoverished access rural and regional tax-payers experience to what should be a 21st Century thoughtful, effective and fair criminal justice system. Those involved within the administration of criminal justice in rural and regional areas, have for too long tolerated government failure. I shall shortly return to the way in which that loss of opportunity to equality plays out for the rural and regional populace.

\section{The government introduces a new sentencing paradigm}

\section{NEW CHANGES}

One of the areas where there is major inequality of opportunity between city and the bush is in sentencing - and particularly in the sentencing of those involved in drug-related criminal offending. On 24 September 2018, the State Government introduced a new sentencing regime. ${ }^{16} \mathrm{I}$ do not see this new regime as ameliorating in any way the disadvantages drugrelated offenders experience in rural, regional or remote NSW. It is difficult to tell at this point what, if any, problems it will actually encounter, but I have sought to identify concerns I fear might arise.

My first comment concerns the Community Correction's ${ }^{17}$ requirement for strict adherence to a doctrine of total abstinence rather than one of harm minimisation insofar as addictive drug rehabilitation is concerned. This becomes important when determining if use of illicit drugs is to count as a breach of parole orders.

In his Second Reading Speech, Attorney General, Mark Speakman SC identified four aspects of 'the most significant criminal justice reform agenda seen for many years':

16 See amendments to the Crimes (Sentencing Procedure Act 1999 (NSW) and Crimes (Sentencing Procedure) Amendment (Sentencing Options) Act 2017 (NSW).

17 Community Corrections is that section of the NSW Corrective Services that oversights parolees and those persons required to complete court ordered Correction and Conditional Release Orders. 
U T S

e PRES S
The reforms are underpinned by the commitment of $\$ 200$ million and will achieve a tough and smart justice system in four ways. First, the reforms will change how offenders are sentenced to ensure they are supervised where necessary. Too many offenders are leaving court without supervision, including domestic violence offenders. Too many offenders are not being made to attend the evidence based programs we offer to reduce their risk of reoffending. (My emphasis)

Secondly, a new regime will address indictable offences at the early stage of the justice process by the early appropriate guilty plea reforms. Thirdly, if offenders pose an unacceptable risk to the community upon completing their sentence of imprisonment, the reforms will ensure a more robust scheme enabling post-sentence supervision in the community or detention in a correctional centre of a small cohort of high risk sex and violent offenders. Fourthly, my colleague the Minister for Corrections will introduce reforms that will implement stronger decision-making regarding parolees and smarter management of them. These reforms are underpinned by evidence about what works and an informed but extensive consultation process. ${ }^{18}$ (My emphasis)

\section{COMMENTS}

There can be little doubt the policy settings embedded within these legislative changes to the sentencing laws will contribute to an increase in the numbers of offenders subjected to post completion of sentence supervision in the community. In countries having a bill of rights, such a scheme of post-sentence supervision is likely to be unconstitutional on the basis of interference with a subject's liberty. At present, the post completion of sentence regime is limited to sex offenders and those convicted of violence, and the proposed reforms at this stage appear limited to them. Greater numbers of those offenders are likely to be caught up in $a$ more robust scheme of post offender supervision. However, I also fear, using the same rational as is used for offenders of violence and sexual assaults, post completion of sentence supervision may be harnessed for the habitual or recidivist offender - taking us back to yesteryear when those who were habitual offenders could be sentenced to a further term of imprisonment simply for being someone who re-offended.

The sentencing reforms (as distinct from the post-sentencing reforms and the reforms proposed for indictable offence procedures) appear to be aimed principally at the sentencing of offenders whose sentences would fall towards or below a sentence of two years imprisonment (say $25 \%$ of the prison population ${ }^{19}$ ). Available for this cohort, in addition to the fulltime incarceration option, are now three levels of community based supervision orders. ${ }^{20}$ This may be a gain for those offenders who, before the new sentencing regime, may have received a period of fulltime incarceration up to two years, ${ }^{21}$ but it may well be far more onerous for others who would have received a non-custodial outcome - even be it a two year suspended

18 NSW, Hansard, Legislative Assembly,-11 October 2011, 10:12am (Mark Spearman JC, Attorney General, Second Reading Speech).

19 On Census night 2016, the figure was 3,191 prisoners amounting to $25 \%$ of the prison population. See Corben (n 8).

20 Intensive Correction Order (taking the place of the existing ICO, suspended sentences and providing a slot for home detention) Community Correction Order (replacing s 9 Bonds and Community Service Orders) and Conditional Release Orders (for lowest level of offending). See NSW, Hansard (n 18).

$21 \quad R$ v Pullen [2018] NSWCCA 264. 
U T S

e PRES S

sentence requiring supervision via a section 12 good behaviour bond. The rationale, as explained by the Attorney was:

We know that community supervision is better at reducing reoffending than leaving an offender in the community with no supervision, support or programs. We also know that community supervision is better at reducing reoffending than a short prison sentence. $^{22}$ (My emphasis)

The Attorney makes clear the legislation will provide:

[A] presumption that an offender convicted of a domestic violence offence will receive either a prison term or a supervised order. This reflects and supports the Premier's priority to tackle domestic violence reoffending in New South Wales ...

In addition a court must not impose an intensive correction order for a domestic violence offence unless satisfied it will adequately protect the victim or any likely coresident of the offender...

The Government wants the court to ensure that domestic violence offenders who receive community-based sentences receive whatever supervision or programs are needed to address their offending behaviour (My emphasis). ${ }^{23}$

The government department charged with administering the sentencing reforms is Corrective Services NSW. Many of the personnel within Corrective Services appear to be highly capable and enthusiastic. But the history of administration within Corrective Services suggests to me that such commitment may not be enough, particularly insofar as rural, regional and remote centres are concerned. For example, distance may mean fly-in, fly-out, or drive-in, drive-out supervisors, which, in turn, may mean an inconsistency in supervisory contact with offenders. Of course, distance is not only a problem for the supervisor but also a problem for the offender, whose resources for travel may be far more meagre than for the supervisor.

Community Corrections officers will have a greater influence in the sentencing proceedings. They now have an opportunity to make recommendations to the sentencing court of programs an offender should be referred to. If a suitable program, say a drug rehabilitation centre or a domestic violence program, is not offered in some regional areas, that may result in an adverse sentencing outcome for an offender.

Another problem of greater supervision lies in the rigidity and inflexibility that comes with closer scrutiny of drug and alcohol use by addicts who have received a supervision order. Total abstinence rather than, say, intoxication, is the test. The smallest consumption of an illicit drug constitutes a breach. Included among what are known as Justice Procedure Offences are breaches of community based sentences whether they be custodial or non-custodial. ${ }^{24}$ Illicit or unauthorised drug or alcohol use, particularly if repetitive, may well be regarded as a community based sentence. There will be an increase in the number of community based sentences being given under the new sentencing regime. Drug testing, when ordered, may also

\footnotetext{
22 NSW, Hansard, (n 18).

23 Ibid.

24 Australian Law Reform Commission, 'Justice Procedure Offences: Breach of Community Based Sentences' in Incarceration Rates of Aboriginal and Torres Strait Islander Peoples (ALRC, Chapter 7) <https:// www.alrc.gov.au/sites/default/files/pdfs/publications/dp84_07.justice_procedure_offences-breach_of_ community-based_sentences.pdf>.
} 
U T S

e PRES S amount to a mandatory requirement, the breach of which (a not entirely unexpected outcome) is also classified as an offence against Justice Procedure.

The argument is that requiring addicts to abstain totally from drugs rather than to minimise their drug use, puts an unrealistic and impossible demand upon almost all addicts. Anyone who loves alcohol or tobacco will readily concede giving up one or the other is demandingly difficulty, and almost impossible to do 'cold turkey'. Those dependent upon or addicted to alcohol or other illegal substance would be no exception. Nearly 17 per cent of juvenile inmates, and 10 per cent of adult inmates (climbing to $15 \%$ for Aboriginal offenders) have recorded as their most serious offence a Justice Procedure Offence. In the case of the adult prison inmates, that currently amounts around 1,300 persons. ${ }^{25}$ The government's stronger decision-making regarding parolees is a euphemism for a stricter compliance approach in respect of parolees backed up by more frequent breach notices. Simply stated, the numbers for Justice Procedure Offending are heading for a substantial increase.

\section{NEW CHANGES (CONTINUED)}

The Attorney explained the changes he was introducing in respect of 'early appropriate guilty pleas reform' against a backdrop of 'a substantial backlog of trials in the District Court, which is leading to significant delays in finalizing indictable criminal cases'.26 Time lapses for guilty pleas between committals from Local Court to District Court often exceeded 220 days, although cases dealt with on the special Rolling Court List had an average delay of 150 days. ${ }^{27}$ The Attorney explained the new scheme:

There are five elements to the legislative reforms. First, the investigating agency that charged the accused person with the offence ... will provide a simplified brief of evidence to the Office of the Director of Public Prosecutions or its Commonwealth equivalent. Secondly, a senior prosecutor ... will review the evidence and file a charge certificate with the Local Court that confirms the charges that will proceed to trial and identifies any charges that should be withdrawn. This will reduce the likelihood that the charges will change closer to the trial date and provides certainty to the defence. Thirdly the prosecutor and the defence lawyer will then be required to have a case conference to discuss the case and to determine whether there are any offences to which the accused person is willing to plead guilty. (My emphasis)

Fourthly, the bill abolishes the substantive committal and committal hearings so that magistrates will no longer be required to consider the evidence and determine whether there is a reasonable prospect that a jury, properly instructed, would convict the accused person of the offence. Instead, magistrates will then need to be satisfied that the new steps certifying the charges and holding a case conference have been completed before committing the matter to a higher court for trial or sentence ... Under the reform the prosecutor will perform a gatekeeping role earlier in the process by certifying which charges will proceed. Fifthly, the bill prescribes sentencing discounts given for the utilitarian value of guilty pleas by introducing a statutory sentence discount scheme.

25 NSW Bureau of Statistics and Research (n 7).

26 NSW, Hansard (n 18).

27 NSW Justice, 'District Court Program Reduces Delays' (Media Release, 9 January 2019). 
U T S

e PRES S
This will provide certainty and ensure that large discounts cannot be granted for guilty pleas that are made late in the process.

In addition to the five elements of legislative reform, additional funding is being provided to the Office of the Director of Public Prosecutions and Legal Aid to ensure the continuity of senior lawyers for both the prosecution and the defence from start to finish. Currently, due to the pressures being placed on the entire criminal justice system, prosecutor and defence lawyers often become involved in cases only very late, Having the same senior prosecutor and defence lawyer in the case throughout its life will increase certainty about the charges, avoid last-minute changes in charges and pleas at trial and improve communications with victims about the process. The Government is also investing in the systems and processes in agencies and the court providing ongoing monitoring so that issues can be managed as they arise during the implementation of the charges. ${ }^{28}$ (My emphasis)

\section{COMMENT}

Simplified briefs are, as I understand it, to be prepared by an investigating agency. That usually would mean the NSW Police. The Federal Police, working for the Commonwealth, are covered by the new committal scheme but not by the fixed discount for an early plea of guilty. Using the 2017 year's count of charged matters, indictable charges may amount to about 14,000 charges (a percentage of which would be exclusively Commonwealth matters). In some indictments, both State and Federal charges are laid. In indictable State matters where the local police have done the investigation, laid the charge and generally have carriage of the matter, a simplified brief passed on to the local branch of the NSW Solicitor for Public Prosecutions may present no problem. However, where the investigating agency is located in Sydney or Canberra, problems preparing the simplified brief of evidence seem more likely, particularly so if a dedicated squad - say the homicide squad or special task force - has taken the lead in the investigation and charging. The simplified breach seems predicated upon an assumption that an investigation is complete or nearly complete by the time a simplified brief is prepared. But where volumes of telephone taps, CCTV footage, SMS texts, office files or other forms of evidence have yet to be examined, the final brief may rely upon a quantum of evidence not disclosed in the simplified brief. This may be particularly true for Commonwealth matters, conspiracy matters and offences alleging ongoing criminal conduct. Where 'roll-over' witnesses, particularly co-accused, are being groomed or otherwise persuaded to give evidence, the timetable provided by the legislation may present difficulties to investigating police hoping to secure such evidence and notify defence within the timeframes provided.

Again, the Attorney anticipates continuity of representation by senior lawyers from both prosecution and defence during the period from charging to trial or sentence in the District or Supreme Court. This may be more difficult to achieve in the regions than in metropolitan centres. Supreme Court sitting in the bush are far more infrequent than in the city - and usually are set down on an as-needed basis. District Court sittings are not continuous in those regional centres where it holds sittings. Gosford, Newcastle, Dubbo, Albury and Wagga Wagga may be the exceptions, but elsewhere there are only a small number of sittings scheduled throughout the year. From a defence perspective, some of these centres do not have a senior solicitor to immediately service persons accused of indictable offences. From both

NSW, Hansard (n 18) 
U T S

e P R E S S

prosecution and defence perspectives, the list of court matters to be completed exceeds, at any one sitting, the time allocated for the court's sitting in that centre.

Moreover, it is likely that those appearing in case conferences on the defence side will be local solicitors, some of whom intend to brief out the trial or sentence. While access to electronic conferencing in recent years may have reduced this problem significantly, my experience is many counsels who appear on circuits arrive in town on the morning of a trial and seek a 'short adjournment' to obtain, for the first time, instructions from their client. Sometimes briefing of counsel occurs close to the trial/sentence date when the Court commences its sittings. In every indictable case it is difficult to see every counsel at trial or sentence of a matter having made himself/herself available for case conferences in, say, July when the trial/sentence sittings is scheduled for November and the listing priorities for these sitting is still uncertain. If these conferences are attended by local solicitors who intend to brief out the trial/sentence, there is always a risk counsel will take a view of the case differently to that held by the instructing solicitor. Finally, there is also a cost issue attached to the case conferences requirement. While costs are less visible to the prosecution, they are, nonetheless, incurred. Each time a legal representative appears for a client, there is a cost to the clients. From some defence clients' perspective, particularly if the client is paying the fees, a discount of $\mathrm{x}$ per cent on a sentence may not be worth the two or three grand in legal fees it costs to achieve it.

\section{Lost opportunities and resources impact upon the administration of justice}

Judicial officers administering justice in rural, regional and remote NSW are bound by the same rules and principles as those administering justice in metropolitan Sydney or Newcastle. But the scope of exercising judicial discretions to achieve the most appropriate outcome is far more limited in the bush than in the city. The limitations arise from limited access to, or complete absence of, resources and some programs in rural, regional and remote NSW, many of which are identified in the bullet-point list above.

Section 3A of the Crimes (Sentencing Procedure) Act 1999 (NSW) sets out seven of the purposes for which a court may impose a sentence on an offender. There are other purposes and controls on sentencing to be found in the case law. By virtue of their being legislated, these seven purposes have special prominence. Briefly, they are:

- To ensure an offender is adequately punished for an offence;

- To prevent similar offending by means of personal and general deterrence;

- To protect the community from the offender;

- To promote the offender's rehabilitation;

- To make the offender accountable for his/her actions;

- To denounce the offender's conduct;

- To recognise the harm done to the victim of the crime and the community.

When sentencing an offender, a court motivated by all or some of the purposes set out above, as the relevant case may require, cannot sentence an offender to imprisonment unless satisfied, having considered all possible alternatives, that no penalty other than imprisonment is appropriate..$^{29}$ As matters presently stand, there is a very substantial difference of 'possible

29 Crimes (Sentencing Procedure) Act 1999 (NSW) s 5 (1). 
U T S

e PRES S

alternatives' for a judge who sentences in Sydney than for a judge sentencing in Bourke, Walgett, Tamworth or Dubbo. Sydney offers greater access to Drug Courts, compulsory drug treatment programs, detox facilities, and drug rehabilitation centres than is available in rural, regional and remote areas of NSW.

When measured against need, rural, regional and remote centres in NSW are starved of drug rehabilitation centres. The closest drug treatment centre for Broken Hill is hundreds of kilometres towards the Victorian boarder. Broken Hill is not the only centre isolated from drug rehabilitation facilities ${ }^{30}$. There is a 'Not in my back yard' resistance to the establishment of drug rehabilitation centres, be they focused on detox or therapeutic treatment of drug addiction. The irony is in at least one centre, competing for a record of the most break-andenter offences, the local member has been reported to me as publicly supporting a progressive approach to drug addiction facilities but privately indicating it will never happen while that person is the Local Member. Politicians of all persuasions find it easier to advocate a 'Law and Order - Lock 'em up' approach than investing in any alternative and more humane (not to mention more effective) approaches to crime reduction.

From any offender's perspective, the experience of being charged, brought in dreadful solemnity before a robed austere and fearsome judge and facing a two or three year custodial sentence can be a cathartic moment whereby his/her mind, in terror of incarceration, crystallises the causes of his/her offending and undergoes a newfound willingness to purge those causes through drug rehabilitation. While such a situation often can be shallow with little chance of success, it does constitute three important steps in the rehabilitation cycle: ${ }^{31}$ recognising he/she has a drug problem causing aberrant behaviour; recognising the need for assistance in dealing with it; and expressing willingness to undergo therapeutic treatment for it. This scenario is a common experience of defence counsel and judicial officers at sentencing hearings. Frequently, the defence representative has already made enquires of a suitable detox and or drug rehabilitation centre and provides an acceptance letter and means of transport from the court to the centre.

In my experience, any such proposal should not be automatically dismissed nor embraced but considered according to practice and sentencing principles. Numerous purposes of sentencing might be well served by making such an order: protection of the community from further offending by the offender, promoting rehabilitation, reformation through a program as a means of the offender accepting accountability for his/her offending conduct; the toughness of the rehabilitation course and the quasi-incarceration/isolation from family in completion of the drug rehabilitation program may amount to adequate punishment; the sentencing proceedings provides an opportunity to denounce the offender's conduct; and recognition of the harm done to members of the community.

Drug detox and rehabilitation centres are sparse in the bush. In their absence there is no or little point in having a Drug Court. That is the unfairness. Homebased rehabilitation programs are far less effective than professional treatment centres. None of the bush gaols offer a compulsory drug treatment program. NSW twelve month parliamentary enquiry that brought down a report to Parliament in August 2017.

31 The five steps are: al recognition by the user that his/her drug use has reached a level where it is harmful for him/her and possibly others; b) recognises the need for assistance in dealing with it, c) a claimed willingness to deal with the problem and d) undertakes the necessary treatment; and e) maintains an abstinence or non-harmful level of usage. 
U T S

e PRES S
In such circumstances, when considering all possible alternatives, options open to a sentencing judicial officer sitting in the bush may find the judicial officer bankrupt of acceptable alternatives, thus coming to a view a custodial penalty is the only alternative available.

Gaol is a barbaric form of punishment. As the Attorney noted in his Second Reading Speech quoted above, it is not as conducive to rehabilitation as attendance at programs outside custody. My own experience in 40 years of practicing in the criminal law is it is overwhelmingly destructive of inmates' mental and physical well-being. Recidivism rates within some groups can range from 70 per cent likely to re-offend to re-offending is a certainty. When only the imprisonment option is left, because there are no other reasonable and appropriate options on offer, imposing such a sentence is not only hard on the judicial officer, it is hard to the point of unfairness on the offender and his/her rural, regional or remote community.

I should point out in circumstances such as I have described, there is unlikely to be judicial error in imposing the sentence. The judicial officer is faced with 'Hobson's Choice' because of the need for: adequate punishment; the need for the offender to be accountable for his offending; the need to impose a personal deterrent and to protect the community from the offender (even if only for a period measured in months rather than years); yet ignoring the real likelihood that the offender will return to his/her community with a potential for recidivism exhibited in greater offending that the initial offence.

As the prison gates open providing an inmate a pathway to the community, enter the recidivist. Seventy-six per cent of prisoners housed in NSW gaols on the night of the 2016 census had prior imprisonment as an adult. For Indigenous prison population, that figure climbs to 90 per cent. ${ }^{32}$ Fifty-eight percent of convicted Indigenous prisoners are held in minimum security custody, ${ }^{33}$ suggesting the criminality level of their offending was not high. Twelve per cent of the Indigenous prison population were returned to prison by the State Parole Authority - although the nature of the parole breach is not identified in the statistical material.

\section{Conclusion}

Any insightful examination of allocations made in the 2017-2018 State budget of \$6.7 billion committed to criminal justice and crime reduction will demonstrate beyond contestation that funds are being allocated to sustain a medieval system of unsubtle brutality, unsupported by science, social morality or effectiveness. The approach of this budget - and budgets going back more than a century - supports a barbarous system primarily based on an unscientific response to crime rather than a thoughtful proactive approach to the prevention of crime. The vast weight of expenditure is devoted to 'back-end loading for consequences of crime' rather than 'front-end remediation of the causes of crime'. From the perspective of those living in rural, regional and remote New South Wales, the unfairness is, what little front-end remediation of causes of drug-related crime is available within the State, that availability is not evenly distributed over the State but favours those living in suburban NSW. If something like 80 per cent of rural, regional and remote areas crime is drug-related, the unfairness is best described as gross.

32 Corben $(\mathrm{n}=8)$.

33 Ibid.

International Journal of Rural Law and Policy, No. 2, 2019 
U T S

e PRES S

\section{References}

\section{JOURNAL ARTICLES/BOOKS/REPORTS}

Bureau of Crime Statistics and Research (Bobscar), 'Criminal Court Statistics 2017' (Media Release, 29 May 2018) <www.boscar.nsw.gov.au/Pages/boscar_media_releases/2018mr-NSW-Criminal-CourtsStatistics-2017.aspx>.

Poynton, Suzanne, and Felix Leung, 'Early Indicators of the Impacts of the NSW Driver Licence Disqualification Reforms' (Issue Paper No. 135, NSW Bureau of Crime and Research Statistics, August 2018).

Bureau of Crime Statistics and Research (Bobscar) 'Criminal Court Statistics: NSW Criminal Courts Snapshot: Court Workload by Offence Type, 2017’ <www.boscar.nsw.gov.au/Pages/boscar_court_stats/ boscar_courts_stats.aspx>.

Local Court of New South Wales, Local Court of New South Wales: Annual Review 2017 (Report, 2018) 4. Woodburn, Jessie, Katrina Grech and Don Holmes, 'Why Does NSW have Higher Imprisonment Rates than Victoria' (2019) 145 Crime and Justice Bulletin; see also <www.boscar.nsw.gov.au/Documents/CJB/ cjb145.pdf>.

NSW Bureau of Statistics and Research, NSW Custody statistics *Quarterly update, March 2018).

Corben, S, NSW Inmate Census 2016 - Summary of Characteristics (Statistical Publication No 45, ISSN 08144 1215, October 2017, Corrective Services NSW).

National Rural Health Alliance, Illicit Drug Use in Rural Australia (Factsheet 33, June 2015) 2 <http:// ruralhealth.org.au/sites/default/files/publications/nrha-factsheet-illicit-drugs-0615.pdf>.

Justice Health and Forensic Mental Health Network, Network Patient Health Survey 2015 14; see also Health - Justice Health \& Forensic Mental Health Network, 2015 Network Patient Health Survey Report <www.justicehealth.nsw.gov.au/publications/2015_NHPS_FINALREPORT.pdf>.

NSW Budget Estimates, 2017-18, 7 Justice Cluster <www.budget.nsw.gov.au/sites/default/files/ budget-2017-06/7\%20Justice\%Cluster.pdf>.

Nicholson, J, 'Reconsidering Traditional Custodial Sentencing Policies and Practices' (2018) 147 Precedent.

NSW, Hansard, Legislative Assembly,-11 October 2011, 10:12am (Mark Spearman JC, Attorney General, Second Reading Speech).

Australian Law Reform Commission, 'Justice Procedure Offences: Breach of Community Based Sentences' in Incarceration Rates of Aboriginal and Torres Strait Islander Peoples (ALRC, Chapter 7) <https://www.alrc.gov.au/sites/default/files/pdfs/publications/dp84_07._justice_procedure_offencesbreach_of_community-based_sentences.pdf $>$.

NSW Justice, 'District Court Program Reduces Delays' (Media Release, 9 January 2019).

\section{LEGISLATION}

Crimes (Sentencing Procedure Act 1999) (NSW)

Crimes (Sentencing Procedure) Amendment (Sentencing Options) Act 2017 (NSW). 


\section{CASES}

$R v$ Pullen [2018] NSWCCA 264. 